\title{
Penguatan Ketepatan Pengenalan Wajah Viola-Jones Dengan Pelacakan
}

\author{
Mangaras Yanu Florestiyanto ${ }^{1^{*}}$, Awang Hendrianto Pratomo ${ }^{2}$, Nidya Indah Sari ${ }^{3}$ \\ 1, 2, ${ }^{3}$ Program Studi Teknik Informatika, Universitas Pembangunan Nasional "Veteran" Yogyakarta, DI Yogyakarta \\ Email: ${ }^{1 *}$ mangaras.yanu@ upnyk.ac.id, ${ }^{2}$ awang@upnyk.ac.id, ${ }^{3}$ nidyaindah13@gmail.com
}

(Naskah masuk: 29 Jan 2020, direvisi: 13 Apr 2020, diterima: 18 Apr 2020)

\begin{abstract}
Abstrak
Aplikasi pengenalan wajah sebagian besar berorientasi pada penguatan sistem keamanan dan pemantauan. Aplikasi-aplikasi tersebut banyak dikembangkan akibat adanya kajian penguatan ketepatan pengenalan wajah yang dikembangkan terus-menerus oleh peneliti. Variasi fitur wajah setiap orang yang kompleks dan perubahannya dari waktu ke waktu, bahkan dalam waktu yang singkat menjadikan optimalisasi ketepatan pengenalannya semakin rumit. Studi ini bertujuan untuk meningkatkan performa metode Viola-Jones pada target yang bergerak dengan integrasi algoritma tracking. Algoritma tracking yang diintegrasikan adalah algoritma Continuously Adaptive Mean Shift (Camshift). Algoritma ini merupakan pengembangan dari algoritma Mean Shift yang secara terus menerus melakukan adaptasi atau penyesuaian terhadap distribusi probabilitas warna yang selalu berubah tiap pergantian frame dari sebuah sequence video. Integrasi tracking dengan Viola-Jones signifikan meningkatkan ketepatan pengenalan wajah dibandingkan tanpa tracking yaitu sebesar $96 \%$.
\end{abstract}

Kata Kunci: Pengenalan Wajah, Pelacakan, Viola-Jones, Euclidean Distance

\section{Strengthening the Accuracy of Viola-Jones Face Recognition with Tracking}

\begin{abstract}
Face recognition applications are mostly oriented towards strengthening security and monitoring systems. Many of these applications have been developed due to the study to enhance the accuracy of facial recognition that is being developed continuously by researchers. The variety of sophisticated facial features of each person and their changes over time, even in a short time, makes optimizing the accuracy of the recognition more complicated. This study aims to improve the performance of the Viola-Jones method on moving targets with the integration of the tracking algorithm. The integrated tracking algorithm is the Continuously Adaptive Mean Shift (Camshift) algorithm. This algorithm is a development of the Mean Shift algorithm, which continuously adapts or adjusts to the colour probability distribution that is always changing with each change of frame of a video sequence. Integration of tracking with Viola-Jones has significantly increased the accuracy of facial recognition compared to without tracking, which is $96 \%$.
\end{abstract}

Keywords: Face Recognition, Tracking, Viola-Jones, Euclidean Distance

\section{PENDAHULUAN}

Aplikasi pengenalan wajah sebagian besar berorientasi pada penguatan sistem keamanan dan pemantauan. Sebagian diaplikasikan pada keamanan smart home [1-5], identifikasi [6-12], dan pemantauan [13-17]. Contoh penerapan pengenalan wajah dalam menguatkan sistem keamanan smart home dengan menggunakan data latih dari sosial media untuk meningkatkan ketepatan klasifikasinya [3], mengaplikasikan pengenalan wajah dalam identifikasi tindak kejahatan $[6,9]$, dan aplikasi pengenalan wajah untuk pemantuan kehadiran siswa di kelas [16]. Aplikasi-aplikasi tersebut sangat mungkin 
dikembangkan karena adanya kajian tentang ketepatan dalam pengenalan wajah.

Banyak literatur menyebutkan ketepatan pengenalan wajah merupakan studi yang rumit karena wajah memiliki tingkat kompleksitas yang tinggi [18-23]. Fitur wajah setiap orang sangat bervariasi dan berubah dari waktu ke waktu, baik karena umur yang menua maupun perubahan ekspresi, bahkan perubahan bisa berlangsung dalam waktu singkat [24]. Kecepatan perubahan ekspresi wajah dan variasi fitur wajah dengan kompleksitas tinggi mempengaruhi ketepatan dalam proses pencocokan secara signifikan. Faktor lain yang mempengaruhi ketepatan pencocokan wajah adalah kualitas input yang berupa gambar maupun video tangkapan kamera [25]. Gambar dan video input seringkali diambil dalam lingkungan yang tidak terkontrol, tidak kondusif, dan penuh dengan noise (gangguan) yang tidak diinginkan, baik itu kaitannya dengan pencahayaan maupun latar yang kompleks [19], [26].

Banyak penelitian telah dilakukan untuk mengurai kerumitan studi ketepatan pengenalan wajah antara lain memberikan perlakuan pencahayaan yang berbeda terhadap target dengan beberapa pose [27]. Hasilnya perlakuan pencahayaan yang sama atau hampir sama antara data latih dan data uji memberikan hasil ketepatan pengenalan wajah lebih tinggi dibanding perlakuan pencahayaan yang jauh berbeda. Selain pencahayaan dan pose, kondisi tidak terkontrol lainnya adalah warna atau rona wajah. Rona wajah menyebabkan tingkat pencahayaan yang ditangkap kamera berbeda-beda, dalam eksperimennya gambar berwarna meningkatkan ketepatan pengenalan wajah lebih tinggi dibandingkan dengan gambar grayscale [28]. Dalam penelitian lainnya juga mengadopsi Development Network (DN) yang memiliki ketepatan lebih dari 95\% dalam pengenalan wajah target dengan latar yang kompleks [29-30].

Lingkungan yang tidak terkontrol memaksa peneliti untuk mengenali target jamak dengan menggabungkan metode Haar Cascade dan Eigenface untuk mendeteksi 55 wajah dalam sekali proses dengan ketepatan 91,67\% [31]. Studi lainnya mengungkap bahwa Minimum Eigen Value menggunakan SVM classifier menghasilkan ketepatan pengenalan wajah yang lebih baik untuk target jamak yaitu sebesar 83\% [32]. Peneliti juga mengkaji pengenalan wajah jamak secara real time menggunakan metode Viola-Jones sebagai metode deteksi wajah dan melakukan ekstraksi fitur menggunakan Speeded up Robust Features (SURF), serta memanfaatkan $M$ estimator Sample Consensus (MSAC) dalam pencocokan wajah [33]. Ketepatan pengenalan wajah dengan mengintegrasikan ketiga metode tersebut sebesar $95.9 \%$.

Sementara itu juga dipelajari performa Dlib dan OpenCV, keduanya memiliki performa yang baik dalam mendeteksi wajah [34]. Penelitian lainnya juga membandingkan beberapa metode pencocokan wajah berbasis Principal Component Analysis (PCA) [35]. Hasil studi menyatakan pencocokan dengan Euclidean Distance menghasilkan ketepatan 93.75\%, Chebychev Distance menghasilkan ketepatan 96,87\% dan Manhattan Distance menghasilkan ketepatan sebesar 96,87\%. Sementara dalam literatur lainnya juga mengungkap metode Eigenface menghasilkan tingkat ketepatan tertinggi yaitu $96 \%$ dibandingkan Fisherface dan Local Binary Pattern Histogram (LBPH) [25].

Studi lain melakukan kajian performa metode-metode pengenalan wajah yang populer, membedakan metodemetode pengenalan wajah menjadi 3 (tiga) kategori yaitu 1) appearance-based, dimana metode Kernel PCA menggunakan SVM classifier menghasilkan ketepatan 99,05\% merupakan performa terbaik dibanding metode lain dalam kategori yang sama; 2) feature-based, performa terbaik dalam kategori ini adalah metode SIFT \& MLBP dengan ketepatan sebesar 99,73\%; dan 3) soft computing-based, Gabor Jet diintegrasikan dengan Borda Count Classification (BCC) menghasilkan ketepatan 99,8\% [18]. Integrasi metode Gabor Jet dan BCC memiliki performa terbaik dalam kategori ini. Dalam sebuah penelitian juga membagi metode pengenalan wajah menjadi Holistic Matching Methods, Feature-based (structural) Methods dan Hybrid Methods [36].

Bertolak dari studi-studi sebelumnya, studi ini akan meningkatkan performa pengenalan wajah metode ViolaJones pada target yang bergerak dengan integrasi algoritma tracking. Studi ini mengadopsi algoritma tracking Continuously Adaptive Mean Shift (Camshift). Algoritma ini merupakan pengembangan dari algoritma Mean Shift yang secara terus menerus melakukan adaptasi atau penyesuaian terhadap distribusi probabilitas warna yang selalu berubah tiap pergantian frame dari sebuah sequence video.

\section{METODOLOGI PENELITIAN}

Aplikasi pengenalan wajah dibangun dalam studi ini sebagai metode untuk mendapatkan data tingkat ketepatan dalam pengenalan wajah. Sesuai dengan beberapa literatur, serangkaian proses yang sudah umum dalam pengenalan wajah adalah akuisisi citra, pre-processing, deteksi wajah, ekstraksi fitur wajah, mengolah data fitur dengan machine learning, pencocokan set data latih dengan set data uji, dan menilai hasil pencocokan [19], [26], [33], [37-40].

Proses akuisisi gambar maupun video ditangkap dengan CCTV yang selanjutnya disebut sebagai citra digital. Tahap berikutnya melakukan proses normalisasi terhadap citra digital tersebut dengan gray scaling. Proses ini merupakan preprocessing dan dilanjutkan dengan proses deteksi wajah dengan Viola-Jones. Proses deteksi wajah memanfaatkan OpenCV sebagaimana direkomendasikan oleh [34]. ViolaJones terdiri dari 4 (empat) proses utama yaitu Haar Like Feature, Integral Image, Adaptive Boosting dan Cascade of Classifier [41]. Proses Haar Like Feature didefinisikan sebagai perbedaan jumlah nilai gray scale dari semua piksel dalam area persegi panjang citra yang berdekatan. Area tersebut dapat mencerminkan perubahan gray scale dari fitur lokal target yang akan diekstraksi [42]. Proses Integral Image merupakan proses mendapatkan nilai sebuah piksel dengan cara menjumlahkan semua nilai piksel sebelumnya. Sementara proses Adaptive Boosting dan Cascade of Classifier untuk melakukan klasifikasi dengan melakukan seleksi terhadap fitur 
penting dan mengoptimasi proses pendeteksian. Proses lengkap pengenalan wajah ditunjukkan pada Gambar 1.

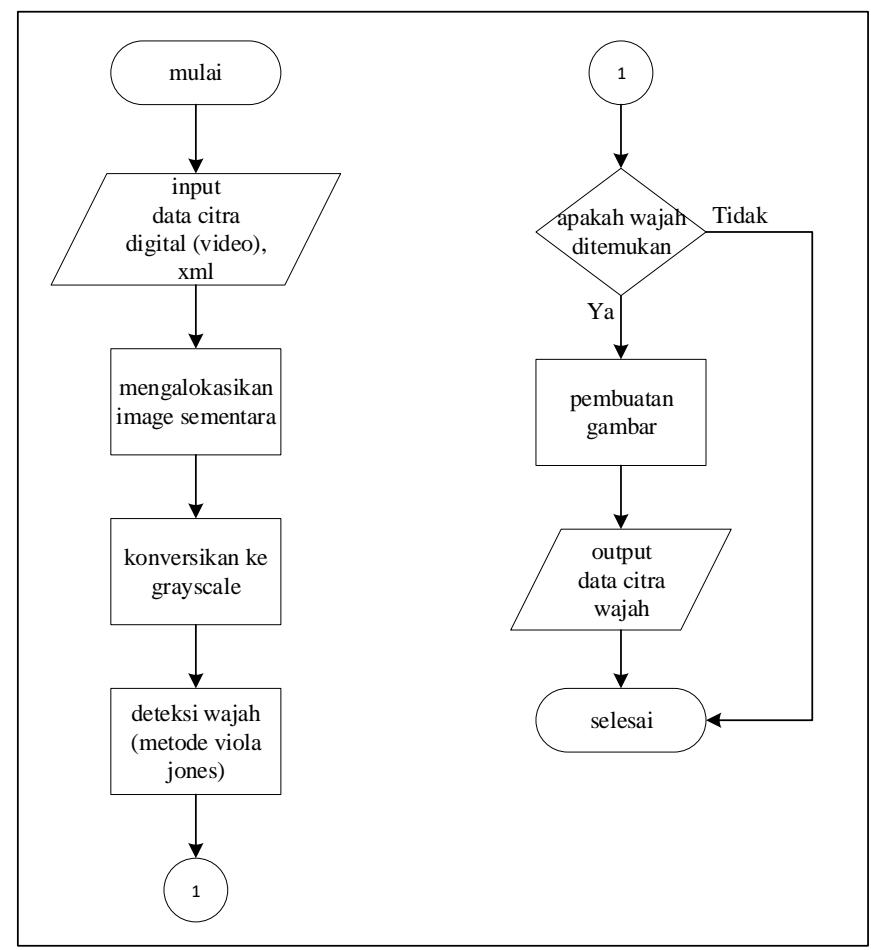

Gambar 1. Proses Pengenalan Wajah Tanpa Tracking

Selanjutnya, sesuai dengan tujuan studi untuk meningkatkan performa pengenalan wajah metode ViolaJones, proses pada Gambar 1 dikembangkan dengan mengintegrasikan dengan algoritma tracking. Algoritma tracking Camshift diimplementasikan pada proses deteksi wajah. Proses tracking akan memberikan label pada setiap target yang terdeteksi oleh kamera, sehingga tidak dilakukan deteksi ulang pada target yang sama. Skenario algoritma Camshift adalah sebagai berikut:

1. Menentukan ukuran awal search window.

2. Menentukan lokasi awal dari search window.

3. Menentukan daerah kalkulasi (calculation region) pada bagian tengah search window dengan ukuran lebih besar dari search window.

4. Mengkonversi frame citra video ke dalam sistem warna HSV (Hue, Saturation, Value), dan dilakukan color histogram lookup dalam calculation region yang akan menghasilkan citra distribusi probabilitas warna gambar.

5. Menerapkan proses sesuai algoritma Mean Shift (satu atau banyak iterasi) dengan input berupa ukuran dan lokasi search window serta citra distribusi probabilitas warna, simpan zeroth moment.

6. Set nilai $\mathrm{x}, \mathrm{y}, \mathrm{z}$, dan head roll yang diperoleh dari langkah 5.

7. Menggunakan nilai $\mathrm{x}, \mathrm{y}$ untuk menentukan titik tengah

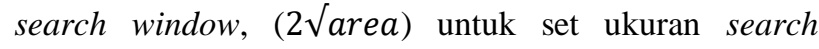
window.
Untuk citra distribusi probabilitas warna gambar, daerah mean (centroid) di dalam search window dapat dihitung sebagai berikut:

Cari Zeroth Moment:

$M_{00}=\sum_{x} \sum_{y} I(x, y)$

Cari First Moment untuk x dan y:

$M_{10}=\sum_{x} \sum_{y} x I(x, y)$ dan $M_{01}=\sum_{x} \sum_{y} y I(x, y)$

sehingga lokasi mean dalam search window (Centroid) adalah:

$x_{c}=\frac{M_{10}}{M_{00}} \quad y_{c}=\frac{M_{01}}{M_{00}}$

dimana $I(x, y)$ adalah nilai warna piksel di posisi $(\mathrm{x}, \mathrm{y})$ pada search window. Orientasi target diperoleh dengan melakukan perhitungan second moments dengan persamaan:

$M_{20}=\sum_{x} \sum_{y} x^{2} I(x, y)$ dan $M_{02}=\sum_{x} \sum_{y} y^{2} I(x, y)$

dimana orientasi objek adalah:

$\theta=\frac{\arctan \left(\frac{2\left(\frac{M_{11}}{M_{00}}-x_{c} y_{c}\right)}{\left(\frac{M_{20}}{M_{00}}-x_{c}^{2}\right)-\left(\frac{M_{02}}{M_{00}}-y_{c}^{2}\right)}\right)}{2}$

Jika:

$a=\left(\frac{M_{20}}{M_{00}}-x_{c}^{2}\right) \quad b=2\left(\frac{M_{11}}{M_{00}}-x_{c} y_{c}\right)$

$c=\left(\frac{M_{02}}{M_{00}}-y_{c}^{2}\right)$

maka panjang 1 dan w lebar dari distribusi centroid adalah

$l=\frac{\sqrt{(a+c)+\sqrt{b^{2}+(a-c)^{2}}}}{2}$
$w=\frac{\sqrt{(a+c)-\sqrt{b^{2}+(a-c)^{2}}}}{2}$

Persamaan tersebut menghasilkan nilai $\mathrm{x}, \mathrm{y}$, rotasi objek, panjang dan lebar (area atau nilai z)

8. Ulangi langkah 3 untuk setiap pergantian frame citra video

Skenario keseluruhan proses pengenalan wajah diintegrasikan dengan tracking dapat dilihat pada Gambar 2 dan Gambar 3. 


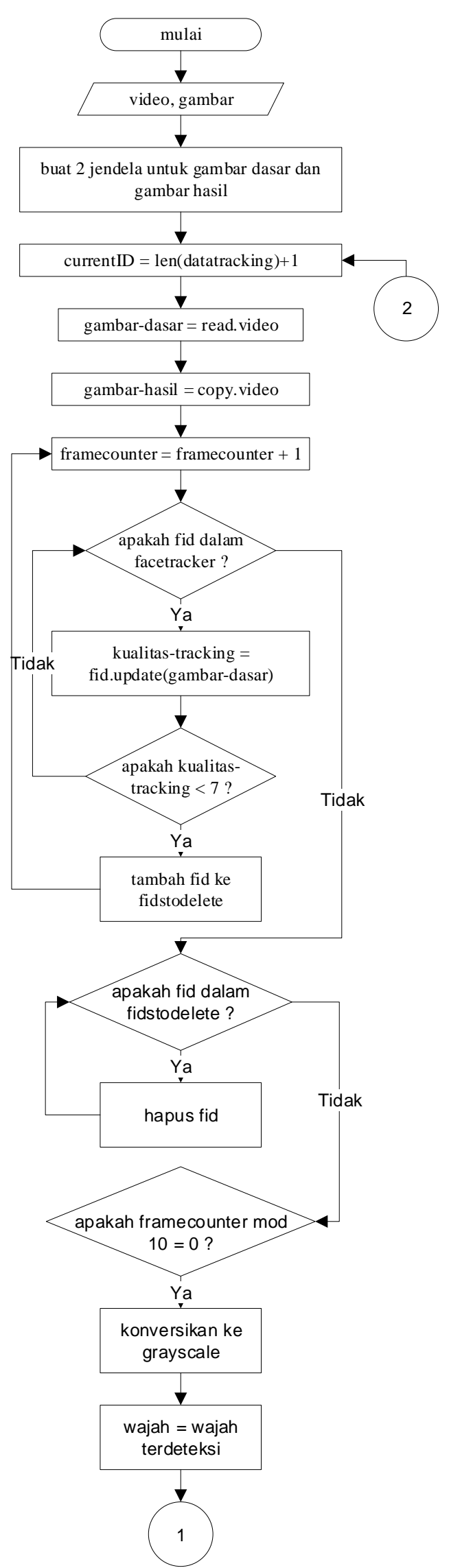

Gambar 2. Proses Pengenalan Wajah Dengan Tracking

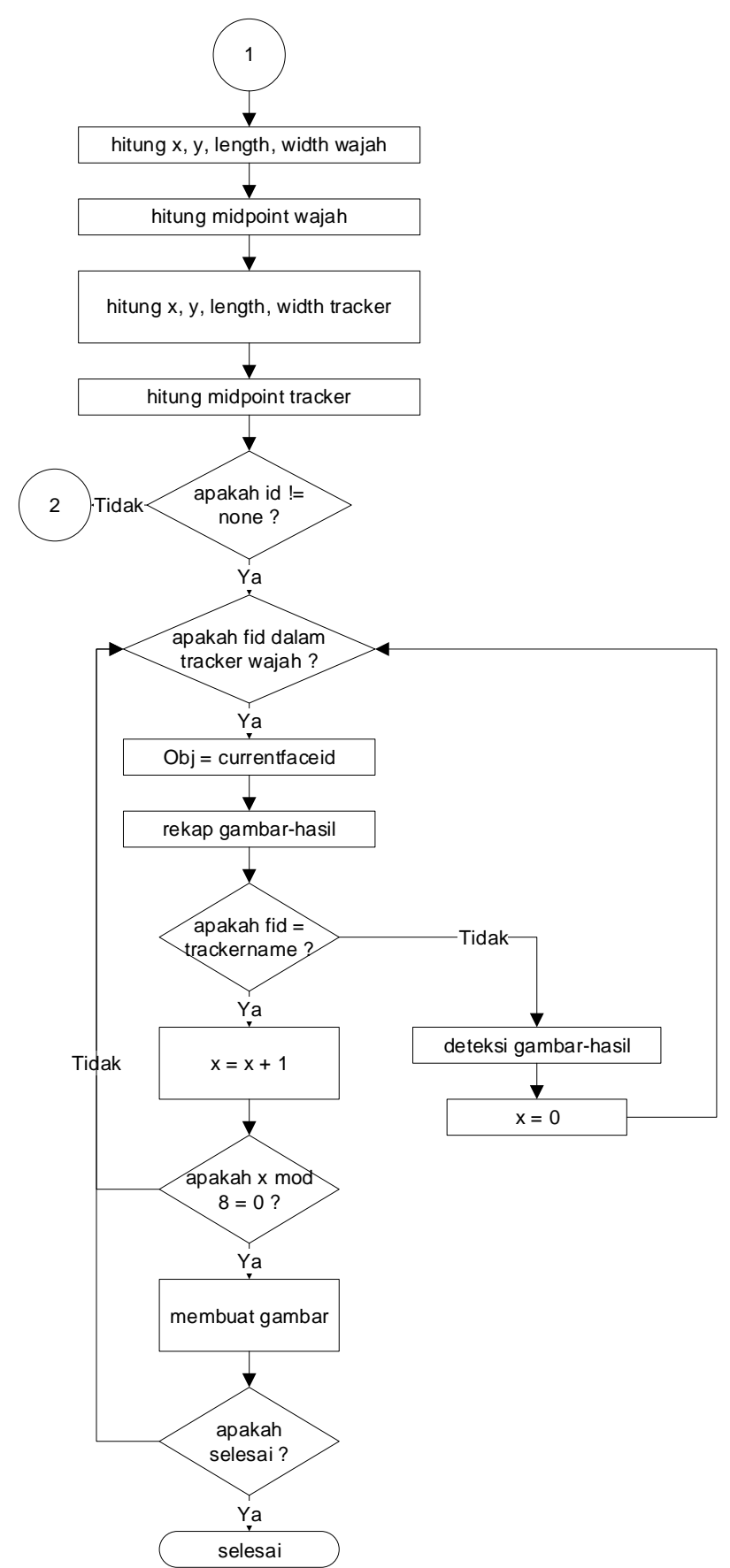

Gambar 3. Lanjutan Proses Pengenalan Wajah Dengan Tracking

\section{HASIL DAN PEMBAHASAN}

Proses diawali dengan pengambilan nilai dari data training, dimulai dengan deteksi wajah pada hasil citra digital yang direkam oleh kamera. Citra wajah yang terdeteksi akan dinormalisasi dan diekstraksi untuk mendapatkan nilai minimal yang digunakan untuk proses pencocokan. Apabila nilai wajah data uji lebih kecil dari nilai ambang maka akan dikenali sebagai anggota dari data latih. 
Aplikasi pengenalan wajah diuji dengan 5 (lima) target yang sudah dilakukan proses latih dan 5 (lima) target tanpa proses latih. Contoh data latih dapat dilihat pada Gambar 4.

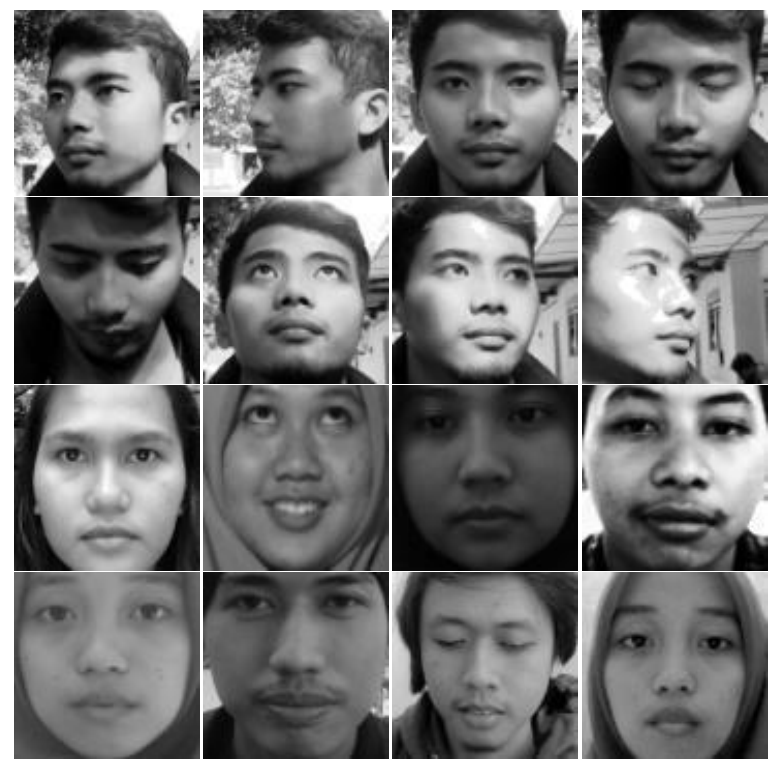

Gambar 4. Contoh Data Latih

Contoh proses deteksi dan pengenalan wajah seperti terlihat pada Gambar 5.

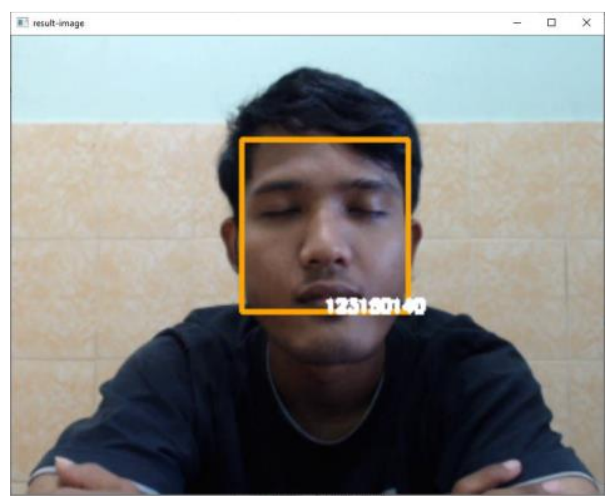

Gambar 5. Contoh Proses Deteksi dan Pengenalan Wajah Dikenal

Pengujian pengenalan wajah dengan tingkat pencahayaan yang berbeda dengan data latih sebagian menghasilkan kesalahan pengenalan, sebagaimana ditunjukkan dalam Gambar 6.

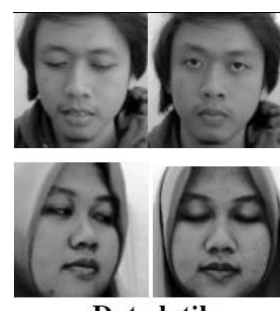

Data latih
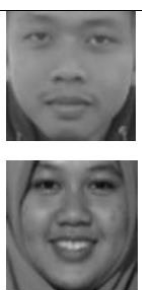

Uji

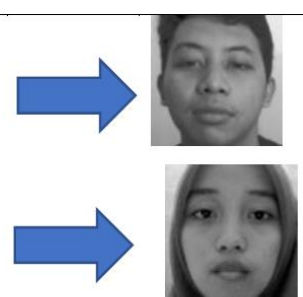

Hasil deteksi
Gambar 6. Pengujian Pengenalan Wajah Dalam Pencahayaan Berbeda
Rata-rata ketepatan pengenalan wajah dengan penambahan algoritma tracking dan tanpa tracking adalah 96\% dan 74,92\%. Perbandingan tingkat akurasi dapat dilihat pada Tabel 1.

Tabel 1. Pengujian Ketepatan Pengenalan Wajah

\begin{tabular}{lrrrr}
\hline & \multicolumn{2}{c}{ Tracking } & \multicolumn{2}{c}{ Non-Tracking } \\
\cline { 2 - 5 } & $\begin{array}{c}\text { Jumlah } \\
\text { Deteksi }\end{array}$ & $\begin{array}{c}\text { Akurasi } \\
(\%)\end{array}$ & $\begin{array}{c}\text { Jumlah } \\
\text { Deteksi }\end{array}$ & $\begin{array}{c}\text { Akurasi } \\
(\%)\end{array}$ \\
\hline Target 01 & 5 & 100 & 69 & 62,37 \\
\hline Target 02 & 5 & 100 & 93 & 71,49 \\
\hline Target 03 & 5 & 80 & 78 & 60,57 \\
\hline Target 04 & 5 & 100 & 63 & 66,85 \\
\hline Target 05 & 5 & 100 & 62 & 74,26 \\
\hline Target 06 & 5 & 100 & 78 & 85,39 \\
\hline Target 07 & 5 & 100 & 78 & 81,13 \\
\hline Target 08 & 5 & 100 & 70 & 86,33 \\
\hline Target 09 & 5 & 80 & 76 & 78,06 \\
\hline Target 10 & 5 & 100 & 65 & 82,74 \\
\hline
\end{tabular}

\section{KESIMPULAN}

Studi ini bertujuan untuk meningkatkan ketepatan pengenalan wajah metode Viola-Jones pada target yang bergerak dengan mengintegrasikan algoritma tracking Camshift. Proses studi diawali dengan mengembangkan aplikasi pengenalan wajah baik tanpa tracking dan dengan integrasi algoritma tracking. Hasil studi menunjukkan bahwa integrasi algoritma tracking secara signifikan meningkatkan ketepatan pengenalan wajah jika dibandingkan dengan hasil tanpa algoritma tracking. Rata-rata ketepatan pengenalan wajah hasil pengujian dengan integrasi algoritma tracking sebesar $96 \%$.

\section{UCAPAN TERIMA KASIH}

Penulis mengucapkan terima kasih kepada Lembaga Penelitian dan Pengabdian Kepada Masyarakat Universitas Pembangunan Nasional "Veteran" Yogyakarta atas dukungan dan arahannya pada penelitian ini.

\section{REFERENSI}

[1] Khattar, S., Sachdeva, A., Kumar, R., \& Gupta, R. (2019). Smart Home With Virtual Assistant Using Raspberry Pi. Proceedings of the 9th International Conference On Cloud Computing, Data Science and Engineering, Confluence 2019, pp. 576-579. https://doi.org/10.1109/CONFLUENCE.2019.8776918

[2] Munir, A., Kashif Ehsan, S., Mohsin Raza, S. M., \& Mudassir, M. (2019). Face and Speech Recognition Based Smart Home. 2019 International Conference on Engineering and Emerging Technologies, ICEET 2019, 
pp. 1-5. https://doi.org/10.1109/CEET1.2019.8711849

[3] Nguyen, T., Lakshmanan, B. \& Sheng, W. (2019). A Smart Security System with Face Recognition A Smart Security System with Face Recognition. School of Electrical and Computer Engineering, Oklahoma State University.

[4] Pawar, S., Kithani, V., Ahuja, S., \& Sahu, S. (2018). Smart Home Security Using IoT and Face Recognition. Proceedings - 2018 4th International Conference on Computing, Communication Control and Automation, ICCUBEA 2018, pp. 1-6. https://doi.org/10.1109/ ICCUBEA.2018.8697695

[5] Wati, D. A. R., \& Abadianto, D. (2018). Design of Face Detection and Recognition System for Smart Home Security Application. Proceedings - 2017 2nd International Conferences on Information Technology, Information Systems and Electrical Engineering, ICITISEE 2017, pp. 342-347. https://doi.org/10.1109/ ICITISEE.2017.8285524

[6] Abdullah, N. A., Saidi, M. J., Rahman, N. H. A., Wen, C. C., \& Hamid, I. R. A. (2017). Face Recognition for Criminal Identification: an Implementation of Principal Component Analysis for Face Recognition for Criminal Identification: an Implementation of Principal Component Analysis for Face Recognition. AIP Conference Proceedings. https://doi.org/10.1063/ 1.5005335

[7] Degadwala, S., Pandya, S., Patel, V., Shah, S., \& Doshi, U. (2018). A Review on Real Time Face Tracking and Identification for Surveillance System. International Conference on Recent Trends in Engineering, Science \& Technology - (ICRTEST 2016). https://doi.org/10.1049/ cp. 2016.1477

[8] Holat, R., \& Kulac, S. (2014). ID Identification by Using Face Detection and Recognition Systems. 22nd Signal Processing and Communications Applications Conference, SIU 2014 - Proceedings, pp.866-869. https://doi.org/10.1109/SIU.2014.6830367

[9] Irianto, Suhendro, Zaini, T. M., \& Karmila, S. (2013). Face Image Retrieval Approach for Criminal Identification in the DC Domain. World Academy of Science, Engineering and Technology, Vol. 82.

[10] Kang, S., Lee, J., Kim, C., \& Yoo, H. J. (2018). B-Face: 0.2 MW CNN-Based Face Recognition Processor with Face Alignment for Mobile User Identification. IEEE Symposium on VLSI Circuits, Digest of Technical Papers, 2018, pp. 137-138. https://doi.org/10.1109/ VLSIC.2018.8502266

[11] Kim, J., Yun, S. S., Kang, B. N., Kim, D., \& Choi, J. (2017). Reliable Multi-Person Identification Using DCNN-Based Face Recognition Algorithm and ScaleRatio Method. 14th International Conference on Ubiquitous Robots and Ambient Intelligence, URAI 2017, pp. 97-101. https://doi.org/10.1109/URAI.2017.7992895

[12] Son, H., Chi, S., \& Kim, K. K. (2012). User Identification Using Face Recognition for Sports Simulator. 9th International Conference on Ubiquitous
Robots and Ambient Intelligence, URAI 2012, pp. 539540. https://doi.org/10.1109/URAI.2012.6463067

[13] Chowdhury, A., Atoum, Y., Tran, L., Liu, X., \& Ross, A. (2018). MSU-AVIS Dataset: Fusing Face and Voice Modalities for Biometric Recognition in Indoor Surveillance Videos. Proceedings - International Conference on Pattern Recognition, pp. 3567-3573. https://doi.org/10.1109/ICPR.2018.8545260

[14] Harikrishnan, J., Sudarsan, A., Sadashiv, A., \& Remya Ajai, A. S. (2019). Vision-Face Recognition Attendance Monitoring System for Surveillance using Deep Learning Technology and Computer Vision. Proceedings - International Conference on Vision Towards Emerging Trends in Communication and Networking, ViTECoN 2019, pp. 1-5. https://doi.org/10.1109/ ViTECoN.2019.8899418

[15] Kaliappan, J., Shreyansh, J., Shanmuga Sundari, P., \& Singamsetti, M. S. (2019). Surveillance Camera Using Face Recognition for Automatic Attendance Feeder and Energy Conservation in Classroom. Proceedings International Conference on Vision Towards Emerging Trends in Communication and Networking, ViTECoN 2019, pp. 1-5. https://doi.org/10.1109/ ViTECoN.2019.8899369

[16] Mao, Y., Li, H., \& Yin, Z. (2014). Who Missed The Class ? - Unifying Multi-Face Detection, Tracking And Recognition In Videos. 2014 IEEE International Conference on Multimedia and Expo (ICME).

[17] Qezavati, H., Majidi, B., \& Manzuri, M. T. (2019). Partially Covered Face Detection in Presence of Headscarf for Surveillance Applications. 4th International Conference on Pattern Recognition and Image Analysis, IPRIA 2019, pp. 195-199. https://doi.org/10.1109/PRIA.2019.8786004

[18] Beham, M. P., \& Roomi, S. M. M. (2013). A Review of Face Recognition Methods. International Journal of Pattern Recognition and Artificial Intelligence, Vol. 27(04), $1356005 . \quad$ https://doi.org/10.1142/ s0218001413560053

[19] Dubey, S. R., \& Mukherjee, S. (2018). A Multi-Face Challenging Dataset for Robust Face Recognition. 2018 15th International Conference on Control, Automation, Robotics and Vision, ICARCV 2018, pp. 168-173. https://doi.org/10.1109/ICARCV.2018.8581283

[20] Kumar, A., Kaur, A., \& Kumar, M. (2019). Face Detection Techniques: a Review. Artificial Intelligence Review, Vol. 52(2), pp. 927-948. https://doi.org/10.1007/ s10462-018-9650-2

[21] Lal, M., Kumar, K., Arain, R. H., Maitlo, A., Ruk, S. A., \& Shaikh, H. (2018). Study of Face Recognition Techniques: A Survey. International Journal of Advanced Computer Science and Applications, Vol. 9(6), pp. 42-49. https://doi.org/10.14569/ IJACSA.2018.090606

[22] Little, A. C., Jones, B. C., \& Debruine, L. M. (2011). The Many Faces of Research on Face Perception. Philosophical Transactions of the Royal Society B: Biological Sciences, Vol. 366(1571), pp. 1634-1637. 
https://doi.org/10.1098/rstb.2010.0386

[23] Wójcik, W., Gromaszek, K., \& Junisbekov, M. (2016). Face Recognition: Issues, Methods and Alternative Applications. In Face Recognition - Semisupervised Classification, Subspace Projection and Evaluation Methods. https://doi.org/10.5772/62950

[24] Jaiswal, S., Bhadauria, S. S., \& Jadon, R. S. (2011). Evaluation of Face Recognition Methods. Journal of Global Research in Computer Science, Vol. 2(7).

[25] Zarei, S. (2018). Face Recognition Methods Analysis. International Journal Artificial Intelligent and Informatics, Vol 1(1). https://doi.org/10.33292/ ijarlit.v1i1.13

[26] An, L., Bhanu, B., \& Yang, S. (2012). Face Recognition in Multi-Camera Surveillance Videos. Proceedings International Conference on Pattern Recognition, pp. 2885-2888.

[27] Boontua, M., Nam-Asa, P., Arwatchananukul, S., \& Aunsri, N. (2018). A Study of Features and Classifiers for Multiple Environment Face Recognition System. 3rd International Conference on Digital Arts, Media and Technology, ICDAMT 2018, Vol. 1(1), pp. 249-253. https://doi.org/10.1109/ICDAMT.2018.8376533

[28] Kim, H.-I., \& Ro, Y. M. (2016). Collaborative Facial Color Feature Learning Of Multiple Color Spaces For Face Recognition. IEEE International Conference on Image Processing (ICIP).

[29] Wang, D., \& Liu, L. (2015). Face Recognition in Complex Background: Developmental Network and Synapse Maintenance. International Journal of Smart Home, Vol. 9(10), pp. 47-62. https://doi.org/10.14257/ ijsh.2015.9.10.06

[30] Wang, D., Zheng, G., \& Liu, L. (2015). Developmental Network and Its Application to Face Recognition. Proceedings of the 2015 27th Chinese Control and Decision Conference, CCDC 2015, pp. 6310-6315. https://doi.org/10.1109/CCDC.2015.7161951

[31] Mantoro, T., Ayu, M. A., \& Suhendi. (2018). MultiFaces Recognition Process Using Haar Cascades and Eigenface Methods. International Conference on Multimedia Computing and Systems-Proceedings, pp. 1-5. https://doi.org/10.1109/ICMCS.2018.8525935

[32] Chinchu, S., Mohammed, A., \& Mahesh, B. S. (2018). A Novel Method for Real Time Face Spoof Recognition for Single and Multiple User Authentication. 2017 International Conference on Intelligent Computing, Instrumentation and Control Technologies, ICICICT 2017, pp. 376-380. https://doi.org/10.1109/ ICICICT1.2017.8342593

[33] Sameem, M. S. I., Qasim, T., \& Bakhat, K. (2016). Real
Time Recognition of Human Faces. ICOSST 2016 - 2016 International Conference on Open Source Systems and Technologies Proceedings, pp. 62-65. https://doi.org/10.1109/ICOSST.2016.7838578

[34] Boyko, N. (2018). Performance Evaluation and Comparison of Software for Face Recognition , based on Dlib and Opencv Library. 2018 IEEE Second International Conference on Data Stream Mining \& Processing (DSMP), pp. 478-482.

[35] Saha, R., Bhattacharjee, D., \& Barman, S. (2014). Comparison of Different Face Recognition Method Based On PCA. International Journal Of Management \& Information Technology, Vol. 10(4), pp. 2016-2022.

[36] Parmar, D. N., \& Mehta, B. B. (2014). Face Recognition Methods \& Applications. International Journal of Computer Applications in Technology, Vol 4(1), pp. 8386. Retrieved from http://arxiv.org/abs/1403.0485

[37] Florestiyanto, M. Y., Himawan, H., \& Silitonga, P. D. P. (2020). Improved Viola-Jones Face Recognition Using Tracking. TEST Engineering \& Management, Vol. 83, pp. 3945-3952.

[38] Huang, C., \& Wei, N. (2012). Comparison And Prospect Study On Multiple Face Detection And Recognition Methods. Proceedings - 2012 International Conference on Computer Science and Service System, CSSS 2012, pp. 1619-1622. https://doi.org/10.1109/CSSS.2012.405

[39] Sharma, R., \& Patterh, M. S. (2015). A New Pose Invariant Face Recognition System using PCA and ANFIS. Optik - International Journal for Light and Electron Optics, Vol. 126(23), pp. 3483-3487. https://doi.org/10.1016/j.ijleo.2015.08.205

[40] Von Söhsten, D., \& Murilo, S. (2014). Multiple Face Recognition in Real-Time Using Cloud Computing, Emgu CV and Windows Azure. International Conference on Intelligent Systems Design and Applications, ISDA, pp. 137-140. https://doi.org/10.1109/ ISDA.2013.6920723

[41] Shamia, D., \& Chandy, D. A. (2018). Analyzing the Performance of Viola Jones Face Detector on the LDHF database. Proceedings of IEEE International Conference on Signal Processing and Communication, ICSPC 2017, pp. 312-315. https://doi.org/10.1109/ CSPC.2017.8305860

[42] Chen, D., Jin, G., Lu, L., Tan, L., \& Wei, W. (2018). Infrared Image Vehicle Detection Based on Haar-like Feature. Proceedings of 2018 IEEE 3rd Advanced Information Technology, Electronic and Automation Control Conference, pp. 662-667. https://doi.org/10.1109/IAEAC.2018.8577211 